\title{
ethic \\ ESPINOSA E A IMANÊNCIA DA ÉTICA DA BEATITUDE EM OPOSIÇÃO AOS AFETOS TRISTES DO PODER TEOLÓGICO- POLÍTICO
}

\author{
ESPINOSA AND THE IMMANENCE OF THE ETHICS OF \\ BEATITUDE IN OPPOSITION TO THE SAD AFFECTIONS OF \\ THEOLOGICAL-POLITICAL POWER
}

RENATO NUNES BITTENCOURT ${ }^{1}$

(FACC-UFRJ/Brasil)

\begin{abstract}
RESUMO
O artigo aborda a relação estabelecida por Espinosa entre a vida ética pautada pela prática da virtude e a beatitude divina, seja pelo caminho da religião ou mesmo da filosofia, em contraponto aos poderes obscurantistas das seitas que promovem as condições mais aviltantes para afastar o homem da genuína felicidade sagrada em vida.
\end{abstract}

Palavras-chave: Beatitude; Virtude; Religião; Conhecimento; Superstição.

\section{ABSTRACT}

The article approaches the relationship established by Espinosa between ethical life based on the practice of virtue and divine beatitude, either by the path of religion or even philosophy, in counterpoint to the obscurantist powers of sects that promote the most demeaning conditions to drive man away from genuine sacred happiness in life.

Keywords: Beatitude; Virtue; Religion; Knowledge; Superstition.

\section{Introdução}

Apesar de Espinosa e sua filosofia estarem enraizadas em um contexto histórico de consolidação da Modernidade, podemos considerar que estamos diante de um poderoso legado extemporâneo. Com efeito, a obra de Espinosa apresenta uma capacidade atemporal de abordar problemas que impactam nossa sociedade hodierna, pois a relação entre filosofia e teologia política é sempre revigorada pelos problemas apresentados pelos homens da religião em suas ações muitas vezes sectárias e ideologicamente inflamadas. Tolerância/intolerância, amor/caridade, justiça, ódio são disposições que constituem o cerne de qualquer vivência religiosa, e a filosofia de Espinosa, calcada na imanência, abarcou todos esses conceitos. As circunstâncias históricas e sociais se modificam, mas o homem apresenta 
caracteres similares no decorrer das eras, evidenciando-se assim um padrão comportamental que nos permite compreender as aporias e dificuldades axiológicas do passado mediante nossa própria interpretação presente. No decorrer do artigo aqui registrado, pretendemos abordar através da filosofia de Espinosa o estatuto da vivência divina e sua inerente beatitude, o caráter sociopolítico da religiosidade e a instrumentalização dos afetos tristes pelo poder sacerdotal.

\section{Religião, poder e ética}

A religião, revestida de base teológica, culto e aparato, apresenta relevância sociopolítica para auxiliar o vulgo a disciplinar as suas paixões e promover a conquista do bem comum mediante os preceitos fundamentais da caridade e da justiça, de modo que o indivíduo constrói um modo de vida pautado pela virtude, que é sempre conveniente. A religião, em sua pureza moral, não é uma prisão para o fiel, mas um caminho repleto de prédicas sapienciais que favorece o desenvolvimento da liberdade perante todas as determinações externas, pois uma vida pautada pelo conjunto de ações virtuosas garante ao homem autonomia, isto é, capacidade de tomar decisões por conta própria, ainda que ele siga exemplos edificantes dos preceitos morais-religiosos de sua fé. Afinal, desprovido de qualquer educação moral, o homem se torna um ser regido apenas pelas inclinações naturais que não são necessariamente más, mas impedem um autodomínio sobre si mesmo, essencial para uma boa vida em sociedade, pois não somos autossuficientes e dependemos sempre das interações propositivas com os demais concidadãos. A práxis religiosa visa, portanto, promover no homem uma organização de vida que favoreça a conquista da beatitude. Dessa maneira, não há oposição necessária entre a fé religiosa e a racionalidade filosófica, pois ambas pretendem desenvolver no homem as condições para a concretização de uma vida feliz, e esta jamais é extrínseca ao caráter virtuoso e a realização de ações meritórias no âmbito coletivo. De acordo com Espinosa,

Todo aquele que busca a virtude desejará, também para os outros homens, um bem que apetece para si próprio, e isso tanto mais quanto maior conhecimento tiver de Deus (ESPINOSA, 2007, 305).

Antes de se corromper pelas disputas políticas e teológicas entre facções, pelos vícios dos seus sacerdotes mesquinhos e pela inserção de elementos estranhos aos princípios fundamentais da vivência divina, qualquer religião expressa princípios benéficos, e, portanto, úteis para o 
florescimento de uma vida feliz no seio social, pois a práxis religiosa se enraíza no ensejo legítimo de o ser humano compreender a imutável essência divina e desvelar os segredos recônditos da realidade, promovendo no fiel o amor para com Deus que se expressa em perspectivas práticas pela generosidade, pela paciência, pelo zelo interpessoal e pela tolerância para com os demais concidadãos. Qualquer grande segmento religioso expressa esse ideário em suas bases teológicas e fortalecem os vínculos do indivíduo com sua comunidade. Afinal, uma pessoa pode vislumbrar desenvolver uma vida monástica, afastada assim das contingências humanas e dos seus problemas usuais, mas será uma vida menos intensa, pois não há aqui o reconhecimento de que o homem é sempre útil para outro homem.

Quem pretende celebrar Deus em uma experiência autocentrada sem pretender que outrem também consiga alcançar esse estado beatífico desconhece a verdadeira essência da piedade religiosa, que é justamente se esforçar para que mais e mais pessoas alcancem um elevado nível de alegria que fortalece assim a própria vida individual e, por conseguinte, intensifica o próprio bem-estar social da cidade. Obviamente que algumas pessoas talvez um pouco mais civilizadas anseiam por um distanciamento concreto em relação ao vulgo (em geral enfadonho, grosseiro e mesquinho), e assim preferem viver em monastérios, nas montanhas isoladas ou mesmo nos desertos, em uma vida ascética de disciplina e autocontrole constante, exercício que certamente favorece o fortalecimento do ânimo e o despojamento em relação aos afetos mais corrosivos da condição humana. Destacado do comum dos homens, o asceta pode talvez se concentrar melhor em sua adoração por Deus e sua inerente busca pela salvação, o que não deixa de ser uma técnica razoável. Contudo, é da própria natureza da razão que o homem dotado de maior sapiência se esforce em esclarecer o vulgo acerca das verdades eternas, ainda que adotando (conforme as circunstâncias sociais e os costumes vigentes em sua época) uma considerável precaução para não colocar em perigo sua própria vida, quando ameaçada por poderes tirânicos contrários ao esclarecimento intelectual das massas. No entanto, temos uma grande variedade de histórias de profetas e líderes religiosos que, preenchidos pela beatitude divina, arriscaram suas respectivas vidas para que transmitissem ao vulgo as mensagens sagradas que não raro desagradam aos poderes estabelecidos e sofreram as sanções arbitrárias impostas por essas governanças despóticas que prosperam politicamente através da ignorância das massas, que permanecem em constante estado de medo e submissão moral, infantiliza a existência do homem comum: "A que ponto o medo 
ensandece os homens! O medo é a causa que conserva e alimenta a superstição" (ESPINOSA, 2003, 6).

A beatitude é a felicidade decorrente da compreensão intuitiva de Deus e é completamente independente de qualquer necessidade de culto externo ou cumprimento de dogmas teológicos criados por escribas e doutores da lei. Os rituais sagrados não são garantias para que o homem conquiste a felicidade inabalável. A circuncisão e o batismo, por exemplo, apenas evocam a aliança do homem para com Deus, mas são sem valor se não há no sujeito o engajamento para realizar ações boas e, portanto, úteis para sua sociedade. A genuína circuncisão é espiritual e o batismo pleno é pelo fogo sagrado, invisível e eterno. Ou seja, a verdadeira religiosidade é vivificada na experimentação monista do homem para com Deus. Quando alcançamos a beatitude, necessariamente somos virtuosos. Quando desenvolvemos essa experiência beatífica em nossas vidas nos colocamos para além das vicissitudes que comumente nos emergem nas turbulentas flutuações de ânimo. Preenchidos pela essência divina, compreendemos a ordem natural das coisas e as leis universais. Por conseguinte, amamos tudo aquilo que existe e queremos que muito mais pessoas alcancem tal nível de júbilo. A verdadeira experiência religiosa, portanto, não é exclusivista, mas nasce de uma disposição alegre de se aspirar que outrem também consiga alcançar tal nível de beatitude, o que é deveras muito útil para a própria vida humana em sociedade, pois aqueles que vivem em conformidade com o amor divino são pessoas mais leais, mais justas, mais temperantes, mais prudentes, mais dispostas em colaborar pela efetivação do bem comum, o que, obviamente, promove a ótima ordenação pública e o progresso genuíno da sociedade mediante a tolerância aos que pensam de maneira divergente, mediante a cooperação na defesa dos interesses soberanos da pátria, mediante a assistência mútua nos casos de necessidade. Esse fortalecimento do elo comum é a raiz da sociedade civil, na qual somos cidadãos ativos e não bestas sem valor autêntico que vivem sob os riscos constantes das intempéries naturais e do arbítrio de governantes inescrupulosos sempre ávidos em espoliar a população desprovida de sólidas garantias jurídicas e constitucionais. Espinosa argumenta:

O homem que se conduz pela razão é mais livre na sociedade civil, onde vive de acordo com as leis comuns, do que na solidão, onde obedece apenas a si mesmo (ESPINOSA, 2007, 349)

Por outro lado, o espírito despótico depende da desagregação da comunhão social para governar sem maiores resistências e assim 
estabelecer seu jugo tirânico através do mutismo do povo, cada vez mais oprimido. Como todo poder autoritário se sustenta moralmente pela sua promiscuidade com um clero distanciado do sofrimento real da comunidade de fiéis, toda desgraça social é considerada uma punição divina pela depravação do povo, quando essas castas dominantes são elas mesmas responsáveis pela miséria coletiva que gera aflição e desgosto naqueles que sofrem. Não há nessa conjuntura disruptiva qualquer senso de misericórdia, benevolência ou propósito de promover as condições reais para a realização da felicidade comum. Se alguém sofre, tanto pior para ele. Somente aqueles que são preenchidos pelo ódio e pelo orgulho moral ousam pretender que as demais pessoas não possam fruir da perfeição divina:

A verdadeira felicidade e beatitude do indivíduo consiste unicamente na fruição do bem e não, como é evidente, na glória de ser o único a fruir quando os outros dele carecem; quem se julga mais feliz só porque é o único que está bem, ou porque é mais feliz e mais afortunado que os outros, ignora a verdadeira felicidade e a beatitude (ESPINOSA, 2003, 50).

A paz social não nasce do silenciamento das paixões ou de qualquer técnica política repressiva, mas pela capacidade de compreendermos a pluralidade dinâmica das individualidades singulares que nos rodeiam e nos esforçarmos ao máximo para que cada pessoa consiga desenvolver condições ótimas de alcançar a felicidade mediante o bom regramento das suas disposições de ânimo. Por isso a verdadeira religião, no fundo, é política, ou seja, se exerce no âmbito da dimensão social do homem e em suas relações prosaicas fundamentais. Conforme argumenta Espinosa,

Se dois se põem de acordo e juntam forças, juntos podem mais, e consequentemente têm mais direito sobre a natureza do que cada um deles sozinho, e quantos mais assim estreitarem relações, mais direitos terão todos juntos (ESPINOSA, 2009, 18).

Espinosa realiza uma contundente crítica aos estabelecimentos eclesiásticos que sustentavam o seu poder moral sobre a consciência dos fiéis através das superstições, disposições marcadas pelo medo e expectação diante do desconhecido e as ameaças vindouras de um aguardado Além-mundo para aquele que não cumprir piamente as regras morais antinaturais. Esses abusos teológico-sacerdotais suprimem toda forma de experiência de comiseração e de perdão, em nome de um Deus de vingança, um Deus da carnificina que se regozija em punir qualquer pecado humano de maneira inapelável. O pecado nada mais é do que um ato do homem que viola regras normativas de conduta moral, ou seja, não 
existe como substancialidade na natureza. O pecado é apenas uma fabulação teológica revestida de caracteres metafísicos para impor ao fiel um padrão de conduta conveniente para o controle social do rebanho, de modo que os afetos individuais permaneçam constantemente fiscalizados e reprimidos. As categorizações do pecado são sempre construções morais situadas historicamente, isto é, não são eternas/atemporais, tal como prega o discurso teológico normatizador da conduta humana. Uma ação considerada virtuosa por um determinado povo pode ser estigmatizada como um grave pecado, por um outro, e essas divergências semânticas são a causa básica de muitas querelas religiosas que desembocam em discórdias mortais entre os litigantes. A moral religiosa faz do pecado uma espécie de marca indelével na alma humana, que somente pode eliminar essa nódoa através de muita penitência, orações, intervenções sacerdotais e, obviamente, pela miraculosa graça divina que transcende qualquer racionalidade. A religião, que em sua essência sagrada visa estabelecer o contato íntimo entre o ser humano e Deus, se torna assim uma experiência amedrontadora que se consolida através da degradação da dignidade humana. Espinosa apresenta uma vigorosa imprecação contra os impostores religiosos que tanto confundem as mentes do vulgo:

A piedade, ó Deus imortal, e a religião consistem em mistérios absurdos e são os que condenam absolutamente a razão, os que têm aversão e rejeitam o entendimento como coisa corrompida por natureza, são esses, suprema iniquidade, que passam por possuir a luz divina. Certamente que, se eles tivessem uma centelha que fosse da luz divina, não andariam tão cheios de soberba idiota e aprenderiam a honrar a Deus e distinguir-se-iam dos outros pelo amor, da mesma forma que agora se distinguem pelo ódio. Nem perseguiriam com tanta animosidade os que não partilham das suas opiniões; pelo contrário, sentiriam piedade deles (se é, de fato, a salvação alheia e não a própria fortuna que os preocupa). Além disso, se realmente tivessem alguma luz divina, ela se veria pela sua doutrina (ESPINOSA, 2003, 10).

Ora, a função social, política e moral da religiosidade consiste em aperfeiçoar o ser humano mediante as prédicas de uma vida virtuosa, conveniente tanto para o indivíduo em questão como para os seus demais convivas e, nessas condições, ela deve reconhecer no ser humano a capacidade de construir uma vida ética que amplifica sua potência de agir e sua indissociável beatitude. Portanto, ver no homem um réprobo miserável que tende a ser um danado eterno somente prejudica ainda mais o desenvolvimento de uma genuína práxis virtuosa, que deve ser calcada 
por um amor sincero do homem para com os outros homens e para com Deus, e não como um contrato normativo que, caso não seja cumprido à risca pelo fiel, resultará na sua perdição eterna. Os cristãos cretinos, sepulcros caiados repletos de podridão interior, sonham em ver seus desafetos submetidos ao fogo infernal e fabulam as imagens mais horrendas desse evento escatológico. O medo pelo sofrimento nas chamas infernais produziu durante séculos e séculos uma massa incontável de sofredores morais, angustiados pelas imagens escabrosas das torturas incessantes no Além-mundo. Na dimensão teológica do catolicismo, mesmo que o fiel possa constantemente se confessar e expiar os seus pecados em vida para obter a salvação eterna, esse procedimento exerce sobre o devoto uma inevitável submissão moral perante a autoridade eclesiástica, dotada de poder de absorver os pecados de todo aquele que sinceramente se penitencia. De acordo com Espinosa,

Se os homens pudessem, em todas as circunstâncias, decidir pelo seguro ou se a fortuna se lhes mostrasse sempre favorável, jamais seriam vítimas da superstição. Mas, como se encontram freqüentemente perante tais dificuldades que não sabem que decisão hão de tomar, e como os incertos benefícios da fortuna que desenfreadamente cobiçam os fazem oscilar, a maioria das vezes, entre a esperança e o medo, estão sempre prontos a acreditar seja no que for (ESPINOSA, 2003, 5).

Não podemos deixar de lembrar os abusos cometidos pela Igreja Católica pela venda de indulgências como uma das formas mais bem logradas economicamente para enriquecer os seus cofres através dos inúmeros pecados dos fiéis que, em sua maioria estultos, pagavam essas taxas aos sacerdotes para que seus pecados fossem pretensamente suprimidos. O abuso alcançou um nível tão disparatado que mesmo as almas dos mortos poderiam obter a mitigação das suas penas no Purgatório mediante o pio pagamento das quantias exigidas pelo clero aos familiares do fiel defunto. Dentro desse imaginário fantasioso, talvez até mesmo almas atormentadas no fogo do Inferno poderiam obter a libertação dessa dor caso houvesse um polpudo pagamento para a autoridade sacerdotal encarregada de libertar o condenado dessas penas eternas, o que evidencia a corrupção eclesiástica mediante sua cobiça ao dinheiro. Vejamos aqui o quanto uma instituição eclesiástica obteve poder sobre sua grande comunidade de fiéis, pois através da apresentação de imagens tenebrosas dos tormentos infernais o medo contínuo foi insuflado na mente do rebanho de devotos cristãos, gerando dominação absoluta sobre suas vidas, seja no plano moral, seja no plano sociopolítico, seja no plano econômico. $\mathrm{Na}$ 
teologia do medo, o sacerdote vive dos pecados do fiel e é conveniente que haja de fato mais e mais pecados, pois assim a estrutura de dominação jamais é destruída. Para cada pecado um preço a ser pago. Espinosa explana sua inquietação com as seguintes palavras:

Inúmeras vezes fiquei espantado por ver homens que se orgulham de professar a Religião cristã, ou seja, o amor, a alegria, a paz, a continência e a lealdade para com todos, combaterem-se com tal ferocidade e manifestarem cotidianamente uns para com os outros um ódio tão exacerbado que se torna mais fácil reconhecer a sua fé por estes do que por aqueles sentimentos. De fato, há muito que as coisas chegaram a um ponto tal que é quase impossível saber se alguém é cristão, turco, judeu ou pagão, a não ser pelo seu vestuário, pelo culto que pratica, por frequentar esta ou aquela igreja, ou finalmente porque perfilha esta ou aquela opinião e costuma jurar pelas palavras deste ou daquele mestre. Quanto ao resto, todos levam a mesma vida (ESPINOSA, 2003, 9).

Uma religião pautada pelo amor, pela promoção da genuína paz social, pela busca da verdade, pela tolerância para com os diferentes e pelo acolhimento ao sofredor, jamais se engrandeceria pelos vícios dos seus seguidores, mas antes pela concretização de uma vida comunitária regida pelo somatório de virtudes dos seus membros, sempre um benefício para a coletividade social. Sempre cabe ressaltar, o bem-estar de um cidadão jamais pode ser categorizado separadamente em relação aos demais indivíduos, e quando ocorre de apenas uma pessoa viver de modo satisfatório mas rodeada de entes miseráveis é antes um exemplo concreto de degenerescência social. Quem consolida uma vida de virtude e sua inerente beatitude sempre se esforçará para que seus concidadãos e compadres também alcancem regozijo similar. Conforme se diz, ninguém é feliz sozinho, seja pelo fato de que toda nossa forma vida de vida é construída de maneira relacional, como também pelo salutar ensejo de que nossos próximos compartilhem intrinsecamente conosco nosso estado de júbilo e para tanto é imprescindível que tal júbilo não seja uma ideia abstrata apenas evocada mentalmente, mas uma vivência imanente. Assim como em uma festa estamos rodeados por nossos entes queridos e amigos ficamos felizes quando todos desfrutam convenientemente do evento, assim também na celebração religiosa e seu correlato exercício da prática virtuosa ampliamos nossa potência de agir quando a graça divina está compartilhada entre todos. Aliás, não há qualquer contradição entre a vivência religiosa e as festividades, pois desde as tradições arcaicas de assírios, hindus, chineses, egípcios, persas, cartagineses, gregos, romanos, 
passando pelos celtas, pelos germanos, pelos tártaros, como também pelos judeus, cristãos, muçulmanos, ciganos, assim como pelos povos originários das Américas ou ainda pelas tribos africanas, a experiência do sagrado jamais se demonstrou absolutamente estranha ao caráter celebratório dos laços sociais. Contra os moralistas abstêmios, dizemos alegremente que Cristo transformou água em vinho e não vinho em água. Em algumas religiões há uma evidente prédica de moderação entre os participantes para que não caiam na lubricidade, mas o espírito do festejo consiste em precisamente romper provisoriamente os liames morais tradicionais. Somente a sisudez tacanha da casta sacerdotal triste e vitalmente impotente repudia a alegria festiva da multidão que celebra a experiência divina por meio dos cânticos e das danças, assim como pessoas desprovidas de grandeza moral que reprovam os costumes alheios imputados como pecaminosos para que melhor escamoteiem os seus próprios crimes. Tal como destacado por Espinosa,

Nenhuma potestade, nem ninguém mais, a não ser um invejoso, pode comprazer-se com minha impotência e minha desgraça ou atribuir à virtude nossas lágrimas, nossos soluços, nosso medo e coisas do gênero, que são sinais de um ânimo impotente (ESPINOSA, 2007, 319).

Algumas correntes puritanas demonizam o consumo de bebidas alcóolicas entre os seus membros e assim vituperam a cultura do vinho e da cerveja, esquecendo-se grosseiramente acerca da importante participação desses líquidos sagrados nos avanços civilizatórios dos povos adeptos da produção, comercialização e degustação desses bens maravilhosos. No ritual da Eucaristia, o padre consome o pão e o vinho, compreendidos como respectivamente o corpo e o sangue de Cristo. Ora, jamais cogitamos imaginar que um padre venha a se embriagar ao consumir o vinho consagrado, e caso tal situação extraordinária aconteça, devemos sempre lembrar que o sacerdote, apesar de sua pia formação, é um ser humano submetido aos limites naturais da carne e assim eventualmente pode cometer deslizes de conduta por imprudência ou desmedida. Por conseguinte, urge destacar que uma coisa, considerada por si só, não é boa nem má, mas sempre deve ser compreendida de maneira relacional com aquele que é afetado por ela. Espinosa salienta que

Tudo o que existe na natureza são as coisas, ou ações. Ora, o bem e o mal não são coisas nem ações. Logo, o bem e o mal não existem na natureza (ESPINOSA, 2012, 87). 
O vinho, a cerveja e as demais bebidas embriagantes são dignos artefatos humanos e somente a compleição do consumidor desses líquidos determina se eles são circunstancialmente bons ou ruins. Para um boêmio a bebida alcóolica é salutar, para um dispéptico é prejudicial, já para um falecido é indiferente. Sem pretendermos nos alongar nessa reflexão, mas cabe ainda destacar que para uma mesma pessoa uma dada coisa pode afetá-la de diversas maneiras: para esse alegre boêmio, a cerveja lhe é aprazível. Caso venha a sofrer posteriormente pelos excessos etílicos, a cerveja Ihe será desagradável e caso infelizmente venha a falecer (sabe-se lá quando) os impactos da cerveja em nada mais lhe importarão, pois não terá mais consciência de nada. Lembremos, aliás, que nem mesmo o consumo da água pode ser considerado de maneira absoluta como saudável para a vida humana. Com efeito, se uma pessoa se arrisca a ingerir uma quantidade em torno de 10 litros de água em um único dia pode sofrer dos efeitos da hiponatremia e quiçá vir a falecer. Essa reflexão é importante para a conjuntura de nossa argumentação, pois existe a tendência humana em se depreciar os elementos naturais e mesmo os bens fabricados quando estes prejudicam particularmente um indivíduo, que passa então a fazer um juízo universal de valor negativo acerca dessa coisa sem levar em consideração justamente que a impressão sensória causada por essa mesma coisa na percepção do sujeito pode se modificar conforme as circunstâncias temporais, a sensibilidade do momento, a quantidade da ingestão, dentre outros fatores afins. Conforme exposto por Espinosa,

Só em poucas palavras direi aqui o que entendo por bem verdadeiro e, igualmente, o que é o sumo bem. Para que se compreenda isso corretamente, deve-se notar que "bom" e "mau" só se dizem em sentido relativo, visto que, de diversos pontos de vista, uma mesma coisa pode ser dita boa ou má; assim também com o "perfeito" e o "imperfeito". Efetivamente, coisa alguma, considerada só em sua natureza, pode ser dita perfeita ou imperfeita, principalmente depois que se chega a compreender que tudo o que acontece acontece segundo uma ordem eterna e segundo leis imutáveis da natureza (ESPINOSA, 2004, 10).

Qualquer governo despótico se associa ao poder sacerdotal obscurantista para imperar sobre as massas como se estas fossem um rebanho de cordeirinhos dóceis. Obviamente, os sacerdotes e quaisquer outros tipos de quadro religiosos que fazem de sua fé um regime tirânico sobre as massas, insuflando-as de terror por punições divinas, ódio e intolerância para com aqueles que seguem outros credos não conhecem a essência divina ou se alguma vez já participaram de uma experiência 
beatífica, dela já se esqueceram. Tal como claramente apresentado no comentário de Deleuze sobre a questão levantada por Espinosa,

O tirano precisa da tristeza das almas para triunfar, do mesmo modo que as almas tristes precisam de um tirano para se promover e propagar. De qualquer forma, o que os une é o ódio à vida, o ressentimento contra a vida (DELEUZE, 2002, 31).

Com efeito, viver em Deus significa a ausência de toda disposição de discórdia para com outrem e a tentativa de se empreender esforços concretos pela harmonia social. Sabe-se que muitos adeptos das religiões institucionalizadas adoram a Deus apenas externamente, mas expressam intimamente um ódio incontrolável contra todas as formas de divergência existentes na vida social. Tal fator explica o motivo de encontrarmos tantas vertentes religiosas no mundo e mesmo assim não termos desenvolvido um modo de vida plenamente feliz, inclusivo, acolhedor, que faça valer a dignidade da experiência religiosa como um caminho sensato de condução da existência pessoal em suas mediações concretas na sociabilidade. Esse ponto deve permanecer em destaque: grosso modo, a vivência religiosa da grande maioria das pessoas fiéis a um determinado credo é meramente aparente, desprovida de substancialidade moral, daí toda a hipocrisia, vilania e outras condutas inapropriadas daqueles que deveriam dar exemplo público de sua própria fé.

Há, nesse tipo de situação de degradação religiosa, um descompasso entre palavra e ato, teoria e prática. A plenitude da conduta religiosa ocorre pelas boas ações que são sempre úteis para o gênero humano, e não, obviamente, por um palavreado vazio enunciado por pessoas farisaicas que se vangloriam de sua pretensa elevação espiritual, mas que chafurdam em práticas ignominiosas na dimensão privada ou mesmo na vida pública, quando em uma dada situação necessitam exercer na prática social os preceitos fundamentais de sua fé religiosa. A ontologia de Espinosa compreende que "Deus é causa imanente, e não transitória, de todas as coisas" (ESPINOSA, 2007, 43). O ser humano é um modo finito da substância divina. Logo, não é um ente separado de Deus tal como a compreensão tristonha da teologia moral afirma severamente, mas está imediatamente ligado com o próprio Deus, o que se caracteriza como uma relação monista. Desse modo, se estamos interligados na substância divina, as orações perdem o propósito, pois somente faz sentido expressarmos nossos anseios para alguém que desconhece aquilo que necessitamos. Mais ainda, as orações visam dobrar a suprema vontade divina aos desejos humanos, o que é um completo absurdo, já que Deus não se modifica nem 
se inclina ao homem. Portanto, ao orarmos, não obstante os efeitos benéficos que as preces produzem em nossa interioridade ao nos propiciar conforto moral e confiança na Divina Providência, em nada conseguimos transformar a ordem das coisas, pois, conforme dito, Deus não atua para satisfazer as inclinações humanas, ainda que estas sejam pias e justas.

\section{O sacerdote, o teólogo e o profeta}

Na análise das figuras religiosas, convém que façamos uma rigorosa distinção entre os limites discursivos e axiológicos de cada uma delas.

O sacerdote de uma religião necessariamente não conhece a essência divina intuitivamente e nem mesmo obtém revelações sagradas para partilhar entre os seus acólitos. Não raro o sacerdote, ainda que movido por boa vontade, apenas apresenta a experiência superficial da religiosidade, atuando perante a comunidade de fiéis como uma liderança moral que estimula a adoção de comportamentos pios. Todavia, quando imbuído de sentimentos e de disposições autoritárias e obscurantistas, o sacerdote usualmente manipula a interpretação dos textos sagrados para obter dominação teológico-política sobre os seus fiéis, tornando-os amedrontados e submissos ao seu arbítrio.

O teólogo, dotado de sapiência intelectual e mesmo verve filosófica, está habilitado a interpretar os textos sagrados e estabelecer perspectivas hermenêuticas que tendem a se tornar oficializadas na dinâmica fideísta da religião da qual faz parte. Todavia, caso exerça suas funções sem a honestidade intelectual e a retidão moral necessárias para esclarecer as escrituras sagradas, o teólogo também promove deliberadamente o erro entre os fiéis de seu credo, gerando assim confusão e o afloramento de afetos tristes nessa comunidade religiosa. Ora, tanto o sacerdote como o teólogo são usualmente instrumentalizados pelos poderes tirânicos para que propaguem discursos e exortações morais convenientes para a manutenção de um status quo obscurantista e autoritário, o que viola indubitavelmente as leis divinas que pregam a paz, a concórdia, a justiça e o amor entre os homens.

O profeta, por sua vez, é a personalidade que mais se distancia das demais segmentações religiosas, pois suas capacidades perceptivas Ihe permitem interagir de maneira imediata com o verbo divino e suas revelações sagradas, interpretando-as conforme suas próprias condições de entendimento. O profeta atua como um intermediário efetivo entre a esfera humana e a esfera divina, estabelecendo assim o contato entre ambos, de modo a se cumprir os planos providenciais para a vida humana mediante o cumprimento das determinações divinas. O exercício profético, cabe 
ressaltar, não é apenas uma ação religiosa, mas também hermenêutica e comunicacional, pois o profeta recebe a mensagem sagrada e a transpõe em signos e imagens conforme o seu próprio entendimento e capacidades discursivas. A verdade sagrada revelada ao profeta é inefável, então há um inerente descompasso semântico entre o que é transmitido para essa figura excepcional e o que é posteriormente divulgado para as massas. Por isso não raramente as mensagens proféticas apresentam-se sob uma retórica vivaz prenhe de imagens impactantes, mas também com caracteres misteriosos, cifrados, pois nem sempre a comunidade de fiéis está capacitada a compreender plenamente a verdade divina, seja por falta de piedade, seja por suas limitações cognitivas.

Analisando as narrativas das arcaicas tradições sagradas, constata-se que comumente as atuações proféticas geravam desagravos nos poderes estabelecidos e nas castas sacerdotais que davam suporte teológico para as autoridades políticas, colocando em perigo a própria vida concreta dessas personalidades sagradas conectadas ao verbo divino. O profeta, para manter a pureza da sua experiência religiosa, prefere se manter afastado da convivência social e, por conseguinte, das contingências políticas e intrigas palacianas, pois assim sua autoridade sagrada adquire uma independência moral que impacta todo o establishment social e o poder estabelecido quando sua voz transmite a verdade divina. Temos vários exemplos mítico-históricos de profetas que habitavam os desertos, os cumes das montanhas, as florestas ermas, ou seja, regiões inóspitas que o homem comum não é capaz de suportar por longa duração de tempo. O profeta adota uma prática de vida ascética, extremamente frugal, temperante, de modo que as paixões de ânimo e as inclinações humanas comuns não o aflijam severamente e prejudiquem o bom desenvolvimento de sua obra sagrada. Somente assim o profeta permanece sempre focado na meta divina. Trata-se de um exercício disciplinar razoável, pois a atividade profética não pode ser obstaculizada por elementos alheios ao serviço divino. $\mathrm{Na}$ ausência de contato com os ruídos sociais muitas vezes enfadonhos e estridentes, o profeta permanece em estado de concentração mais apurado na sua obra sagrada, e assim encontra-se mais bem capacitado para receber as revelações divinas sem interferências deletérias. Poderíamos até mesmo inserir aqui um debate sobre as precondições metabólicas para o exercício da profecia, pois trata-se de um estado de consciência modificado, para além do usual, e certamente o profeta, em sua interação imediata com a revelação divina, não apenas apresenta uma capacidade mental de apreensão mais aguçada, mas seu próprio organismo também é mais sensível e suscetível aos fenômenos sagrados. Talvez os jejuns prolongados e a abstinência de certas práticas auxiliem nesse 
processo de conexão humana com a verdade divina. Aproveitemos uma reflexão de Rudolf Otto:

Para esclarecer a natureza do sentimento numinoso convém lembrar como ele se exprime e exteriormente como é comunicado e transmitido de uma psique para outra. A rigor nem é possível "transmiti-lo", uma vez que nem é "ensinável", mas apenas despertável a partir do "espírito" (OTTO, 2007, 100).

O profeta necessita de forte capacidade de imaginação, fundamental para que os quadros divinos recebidos por sua percepção além do comum encontrem uma significação posterior mediante as palavras que serão transmitidas aos leigos. Seja pela observação de eventos naturais como nuvens ou relâmpagos, seja através de visualização de palavras misteriosas em paredes ou nos quatro elementos, o profeta capta um sentido sagrado nesses eventos. Os sonhos também são experiências bastante favoráveis ao exercício profético e exigem capacidade hermenêutica magistral. Essas imagens usualmente se apresentam para o profeta com fortes cargas visuais que inclusive despertam sentimentos de temor reverencial ou de elevação moral quando narradas publicamente, convenientes para a instrução do povo devoto. Cabe ressaltar que estamos aqui abordando com mais vagar a tradição profética veterotestamentária para que fiquemos conectados imediatamente com a argumentação de Espinosa. Contudo, se direcionarmos nosso enfoque para práticas proféticas de outros povos, constaremos o recurso ao êxtase, ao transe, ao uso de substâncias alucinógenas, ao aruspício, dentre outras possibilidades de conexão do indivíduo sagrado com a dimensão divina e as revelações especiais que daí decorrem. Cada povo, ao instituir suas práticas sagradas, configura os rituais proféticos das maneiras mais abstratas ou mais materiais, mas tais diferenciações em nada rebaixam um profeta xamânico em relação ao profeta judaico, por exemplo. Afinal, o papel sagrado do profeta consiste em transmitir para os homens seculares a verdade divina, recebida sob a forma de símbolos ou palavras usualmente incompressíveis para o vulgo, transcrevê-las de maneira inteligível para que assim a comunidade de fiéis desenvolva uma vida regida pela piedade e pela probidade social. Não se espera de um profeta que agrade aos homens mediante a difusão de mensagens melífluas que impedem a correção moral dos costumes. Por isso o profeta é uma pessoa que, conforme as contingências sociais e políticas, corre permanente risco de morte, pois as mensagens por ele difundidas para os seus pares nem sempre são de bom tom. Todavia, a vocação do profeta exige paciência e resignação diante desses percalços, pois instruir 
os ignorantes com as eternas verdades divinas é um exercício civilizatório para a boa construção de uma sociedade regida pela justiça, pela caridade e pelo respeito pelas instituições, e nem sempre a massa humana anseia por tal modo de vida, genuíno caminho para a beatitude. Mesmo que o profeta participe da vida política da comunidade como uma espécie de conselheiro moral, sua autoridade sagrada jamais se deixa cercear pelos interesses governamentais quando estes conflitam com as leis divinas.

Os homens comuns são geralmente impactados por efeitos extraordinários, pois sua contumaz pobreza de espírito impede-lhes de avivar uma experiência religiosa mais intensa sem os estímulos visuais. Por isso fortalecem sua fé através da ocorrência dos ditos milagres e somente reconhecem uma autoridade sagrada quando esta realiza tais prodígios. 0 milagre, analisado conforme a conceituação de Espinosa, nada mais é do que um acontecimento que o homem comum, desprovido de conhecimento das causas naturais, considera como um fenômeno divino de exceção que modifica a própria ordem da realidade. Se porventura nosso conhecimento das leis físicas fosse mais amplo, o que chamamos de milagre seria explicado através de conceitos científicos. Aliás, a própria experiência religiosa reprova moralmente aqueles que demandam por demonstrações miraculosas para que sua devoção seja fortalecida, pois a verdadeira fé na verdade divina pressupõe amor pleno e uma vida virtuosa, o que já deveria bastar para um crente. Se um profeta ou o próprio Cristo realizaram prodígios espetaculares, tais acontecimentos decorriam dessa necessidade grosseira dos leigos por sinais evidentes. A fé genuína não consiste em se acreditar no suprassensível, mas em se desenvolver uma vida prática talhada pela realização constante de atos virtuosos, que promovem tanto a felicidade pessoal como a satisfação comum.

Na continuação de nossa argumentação, cabe ainda apresentarmos diferenças axiológicas entre os profetas hebreus e a persona do Cristo: os primeiros, escolhidos por Deus para que transmitissem as verdades eternas para o dito povo eleito, relacionavam-se com o Ser Supremo em um viés nitidamente hierárquico e extrínseco, ou seja, Deus submetia mediante sua todo-poderosa autoridade a humanidade do profeta ao seu ensejo de transmitir para os judeus os retos conhecimentos e ensinamentos morais para a correção dos hábitos através de mandatos hierarquicamente verticais. Já Cristo, plenamente consciente de seu monismo para com o Pai, enunciava a Boa Nova como uma revelação interior, na qual Deus se expressava diretamente em seu âmago sem qualquer manifestação externa e heterônoma. Por outras palavras, os profetas se submetiam piamente aos soberanos desígnios ulteriores de Deus, enquanto Cristo, conectado imediatamente na esfera divina, enunciava a mensagem evangélica como 
um participante imanente na obra salvífica de redenção do gênero humano mediante a aplicação concreta das prédicas da caridade e do perdão incondicional.

Espinosa apresenta no cap. II do Tratado Teológico-Político uma investigação apurada sobre o vaticínio dos profetas hebreus, analisando suas peculiaridades estilísticas. Conforme Espinosa argumenta, a verdade divina, apesar de sua postulada unicidade de conteúdo, poderia ser representada discursivamente através de estilos distintos, de acordo com a visão de mundo do profeta, que interpretaria o verbo divino mediante o conjunto de conceitos próprios de sua mente, apresentando então a mensagem divina através do seu revestimento pessoal. A própria revelação divina variava de profeta para profeta, conforme o seu temperamento, a sua imaginação e as opiniões que anteriormente perfilhava. Espinosa aponta que

As variações que se verificavam em função do temperamento eram assim: se o profeta era alegre, eram-lhe reveladas vitórias, a paz e tudo o que é motivo de alegrias para os homens, visto as pessoas com esse temperamento costumarem imaginar com frequência semelhantes coisas; se, pelo contrário, ele era macambúzio, revelavam-se-lhe as guerras, os suplícios e todos os males; em suma, conforme ele fosse bondoso, afável, irascível, severo, etc., assim estaria mais para estas ou para aquelas revelações. Em função da imaginação também se verificavam diferenças tais como: se o profeta era requintado, requintado era também o estilo em que apreendia a mente de Deus; se, pelo contrário, era confuso, apreendia-a confusamente. Outro tanto acontece com as revelações por imagens: se o profeta era um rústico, apareciam-lhe bois e vacas; se era, porém, soldado, apareciam-lhe chefes e exércitos; se era, enfim, um homem da corte, o que Ihe aparecia era o trono real e coisas semelhantes (ESPINOSA, 2003, 35-36).

Nessas condições, por mais que se postule a não-interferência pessoal do canal no processo de recepção de uma mensagem, ela sempre será decodificada em uma estrutura linguística específica que, por sua vez, reproduz o nicho sociocultural no qual esse canal se encontra inserido. Assim como água que desce do alto da montanha absorve todos os sais e sedimentos até chegar na fonte onde homens e animais se regalam com suas salutares propriedades, assim também a mensagem divina, ao ser apreendida pelo profeta, é processada semanticamente através dos traços pessoais dessa distinta figura. 


\section{O filósofo e a vida virtuosa}

O filósofo é a pessoa que, fora do âmbito religioso-sacerdotal, talvez esteja mais capacitada a compreender a essência divina e fazer de sua prática de vida um exercício constante de conduta proba, que sem dúvida exercerá sobre os seus convivas um efeito positivo de demonstração de uma efetiva dignidade religiosa, assim como consequências práticas que beneficiam os seus interlocutores, através do compromisso incondicional com a verdade e a virtude. O filósofo compreende a essência divina sem a mediação do culto e dos aparatos, pois sua relação com Deus é de mente para mente, uma experiência interior, mediada pela racionalidade que permite a compreensão da essência eterna da natureza: "A mente humana tem um conhecimento adequado da essência eterna e infinita de Deus" (ESPINOSA, 2007, 143). Por isso o filósofo, exceto caso o queira por possíveis costumes piedosos, prescinde de rituais e de orações em sua prática de vida ética. Afinal, ninguém é menos fiel pelo fato de não orar frequentemente. Mesmo na experiência cristã original as preces tinham importância reduzida, pois não são fórmulas especiais decodificadas em palavras consagradas que conectam o homem com Deus, mas sim a ação virtuosa constante (que, sempre importante salientar, nunca é extrínseca ao convívio social, pois a vida ética não se desenvolve através do autoisolamento perante o resto da humanidade circundante). E mesmo que o fiel queira transmitir seu amor sincero para com Deus através de orações, as palavras que despontam em sua mente são o principal testemunho de sua fé sincera. A oração fortalece as disposições de ânimo do fiel, mas desvinculadas de uma vida ética são estéreis. Com efeito, muitos devotos despendem grande tempo diário em ladainhas intermináveis e são mesmo assim moralmente perversos, mesquinhos, pois não realizam as ações virtuosas mais basilares predicadas por sua religião. Melhor seria se utilizassem o tempo aplicado nas preces para a concretização de efetivos benefícios públicos. Rezar sem trabalhar para o progresso da humanidade é um ato espúrio. Sabemos que na conjuntura sociopolítica dominada pela visão de mundo teocêntrica, as cabeças pensantes (filósofos, homens das ciências e das artes) eram sempre vistas sob suspeita, mesmo que apresentassem ideias rigorosamente adequadas ao crivo cristão. Quem pensa é sempre perigoso conforme a ótica reativa e odienta do poder tirânico, pois as ideias se propagam entre as pessoas e desmascaram fabulações mentirosas que impedem a compreensão precisa da natureza. Por isso tantos pensadores foram cerceados, perseguidos e mortos por esses poderes despóticos. Muitos pensadores renomados foram considerados heréticos ou libertinos por desenvolverem em suas vidas uma 
conduta laica, que necessariamente não é incompatível com a prática ética. Com efeito, a religião institucional pode ajudar no processo de organização moral da vida individual, mas sem retidão de princípios essa religião é letra morta. A virtude ética, portanto, não depende da religião. Podemos inclusive amar Deus sem sermos adeptos de uma determinada religião, alternativa bastante chocante para as mentalidades tacanhas que controlavam outrora o poder teológico-político e ainda ousar impor sua agenda ideológica excludente e reativa sobre aqueles que não se submetem ao seu discurso autoritário. Tanto pior, a condenação moral-política ao ateísmo contaminou até mesmo uma das sumidades da filosofia moderna, grande contribuidora para os fundamentos da axiologia liberal, a saber, John Locke, conforme podemos constatar nas linhas a seguir:

As promessas, os pactos e os juramentos que formam as ligaduras da sociedade humana não podem ter valor para um ateísta. A retirada de Deus, mesmo que só em pensamento, a tudo dissolve. Além disso, aqueles que por seu ateísmo, enfraquecem e destroem toda a religião não possuem sequer uma pretensão de religião na qual possam basear o privilégio de uma tolerância (LOCKE, 2007, 85).

Em uma sólida filosofia política imanente, apenas os intolerantes não são dignos de tolerância, pois atentam, com seus preconceitos e sentimentos odiosos, contra o bem comum e assim são perigosos para uma salutar organização social. A proposta de Locke é intolerante em relação aos ateus e fundamenta assim as bases da boa sociedade civil ao crivo religioso, o que seria justamente superado pelas vertentes laicas posteriores que embasam nossa constitucionalidade moderna. A figura do "ateu virtuoso" (que muitas vezes era apenas um sujeito que não comungava de uma fé religiosa tradicional) colocava em contradição a hipocrisia fétida daqueles que apenas celebravam a devoção divina de maneira superficial, aparente. O que Espinosa demonstra em seu sistema filosófico, em especial n'Ética, é a elaboração de um rigoroso esquema ontológico-epistemológico que desemboca na compreensão imanente da essência divina e da condição humana com suas potencialidades e limitações, e como é possível alcançar o estado de regozijo existencial pela preservação de nossas faculdades racionais sem nos precipitarmos no abismo das flutuações viciosas que jamais nos concedem tranquilidade e que exigem sempre mais e mais estímulos fortes para que vivamos em uma falsa concepção de prazer sensório, jamais satisfeito. Para Espinosa, 
A beatitude não é o prêmio da virtude, mas a própria virtude; e não a desfrutamos porque refreamos os apetites lúbricos, mas, em vez disso, podemos refrear os apetites lúbricos porque a desfrutamos (ESPINOSA, 2007, 409).

E assim elabora-se uma ética prática, cujo caminho é árduo, mas que, trilhado com disciplina e discernimento intelectual, promove a consolidação da virtude e da sua imediata beatitude concreta mediante o conhecimento dos atributos divinos e de sua manifestação em nós enquanto modos finitos da substância divina. Eis assim uma experiência imanente do homem para com Deus, sem qualquer necessidade de mediação teológico-sacerdotal, sem cultos, sem dogmas. Eis aí o perigo maior para as autoridades eclesiásticas obscurantistas, que impedem o acesso humano ao bem divino e à verdade divina. É possível, portanto, conhecermos Deus sem o suporte da rígida moral religiosa. A Filosofia, tal como construída por Espinosa no conjunto de sua obra, evidencia com maestria essa tese.

\section{Considerações Finais}

Conforme os esforços intelectuais apresentados no presente texto, acredito que é explícita a grande relevância das reflexões filosóficas apresentadas por Espinosa na sua análise sobre a relação entre a ética como experiência concreta e a teologia política, evidenciando-se assim as bases imanentes da religiosidade institucionalizada e as contingências sectárias que a tornam uma vivência afastada da verdadeira beatitude divina. As figuras esclarecidas do passado sempre sofreram toda sorte de ações deletérias quando se propunham a enfrentar as tradições obscurantistas com as armas da racionalidade, e dentre essas contribuições para o progresso da condição humana, sem dúvida a desmistificação dos artifícios teológicos foi uma das grandes heranças para o processo de construção de uma vida ética emancipada do esteio da moral religiosa enquanto asilo da ignorância. A separação entre poder temporal e institucionalidade eclesiástica é fundamental para o avanço social da humanidade moderna, por isso devemos sempre permanecer vigilantes quando figuras autoritárias, alheias aos interesses do bem comum e desvinculadas de qualquer afeto sincero pela experiência divina, ousam submeter a comunidade social aos parâmetros de uma agenda política moralista, intolerante, reacionária e irracionalista. Canalhas se apropriam do nome de Deus para propagar mentiras contrárias ao bem comum e para enriquecer desavergonhadamente às custas da boa-fé do homem comum facilmente seduzido pela retórica desses falsos pastores. Nossa laicidade constitucional, conquistada com os árduos esforços de nossos esclarecidos 
predecessores, é assim ameaçada por espectros teológico-políticos obscurantistas e cabe então àqueles que amam a democracia substantiva e a soberania da coisa pública rechaçar essa escória degenerada.

\section{Notas}

1 Doutor em Filosofia pelo Programa de Pós-Graduação em Filosofia da Universidade Federal do Rio de Janeiro. Professor da Faculdade de Administração e Ciências Contábeis da Universidade Federal do Rio de Janeiro.

\section{Referências}

DELEUZE, Gilles. Espinosa: filosofia prática. Tradução: Daniel Lins e Fabien Pascal Lins. São Paulo: Escuta, 2002.

ESPINOSA, Baruch de. Breve tratado de Deus, do Homem e de seu bemestar. Tradução: Emanuel Angelo da Rocha Fragoso e Luís César Guimarães Oliva. Belo Horizonte: Autêntica, 2012.

ESPINOSA, Baruch de. Ética. Tradução: Tomaz Tadeu. Belo Horizonte: Autêntica, 2007.

ESPINOSA, Baruch de. Tratado político. Tradução: Diogo Pires Aurélio. São Paulo: Martins Fontes, 2009.

ESPINOSA, Baruch de. Tratado teológico-político. Tradução: Diogo Pires Aurélio. São Paulo: Martins Fontes, 2003.

ESPINOSA, Baruch de. Tratado da reforma da inteligência. Tradução: Lívio Teixeira. São Paulo: Martins Fontes, 2004.

LOCKE, John. Carta sobre a tolerância. Tradução: Ari Ricardo Tank Brito. São Paulo: Hedra, 2007.

OTTO, Rudolf. O sagrado. Tradução: Walter O. Schlupp. São Leopoldo: Sinodal/EST; Petrópolis: Vozes, 2007. 